\title{
Long-term observation of black carbon aerosols at an urban location over the central Indo-Gangetic Plain, South Asia
}

\author{
Sambhawika SRIVASTAVA ${ }^{1}$, Manish KUMAR ${ }^{1}$, Ram S. SINGH ${ }^{2,3}$, Birendra N. RAI ${ }^{3}$, \\ Rajesh K. MALL ${ }^{1,2}$ and Tirthankar BANERJEE ${ }^{1,2 *}$ \\ ${ }^{1}$ Institute of Environment and Sustainable Development, Banaras Hindu University, Varanasi, India \\ ${ }^{2}$ DST-Mahamana Centre of Excellence in Climate Change Research, Banaras Hindu University, Varanasi, India \\ ${ }^{3}$ Department of Chemical Engineering and Technology, Indian Institute of Technology-Banaras Hindu University, \\ Varanasi, India \\ *Corresponding author: tb.iesd@bhu.ac.in; tirthankaronline@gmail.com
}

Received: June 4, 2018; accepted: January 14, 2019

\begin{abstract}
RESUMEN
Se presentan las primeras mediciones a largo plazo de aerosoles de carbono negro $(\mathrm{CN})$ en una ubicación urbana de la llanura indogangética media (IGP, por sus siglas en inglés). Tanto las variaciones a corto como a largo plazo en CN de 2009 a 2013 se analizan con énfasis específico en la variación de las fuentes de CN, la meteorología, la tendencia y el posible mecanismo de transporte a través de la IGP. Se observó una carga de $\mathrm{CN}$ excepcionalmente alta con una media $( \pm \mathrm{DE})$ de $11.8( \pm 8.6)$, con un patrón estacional fuerte y constante (mediana: 8.8; rango: 1.4-48.0 $\left.\mu \mathrm{g} \mathrm{m}^{-3}\right)$. El aumento específico en el invierno $\left(21.5 \pm 9.9 \mu \mathrm{g} \mathrm{m}^{-3}\right)$ y la temporada post monzón $\left(17.4 \pm 10.2 \mu \mathrm{g} \mathrm{m}^{-3}\right.$ ) fue consistente con el aumento de las emisiones domésticas y la quema de residuos agrícolas. La masa de $\mathrm{CN}$ fue influenciada principalmente por fuentes locales, mientras que el cambio repentino en la concentración de $\mathrm{CN}$ fue consistente con el cambio en Delta-C, lo cual indica que las emisiones provienen principalmente de fuentes biogénicas de $\mathrm{CN}$. Además de las fuentes, la altura de la capa límite atmosférica influyó considerablemente en la carga de CN. También se calculó una tendencia creciente monotónica estadísticamente significativa en la concentración de $\mathrm{CN}\left(0.9 \mu \mathrm{g} \mathrm{m}^{-3} \mathrm{yr}^{-1}\right)$ junto con sus correspondientes límites de incertidumbre de $95 \%\left(0.38-1.52 \mu \mathrm{g} \mathrm{m}^{-3} \mathrm{yr}^{-1}\right)$. Tal aumento gradual en CN fue consistente con el aumento potencial en sus fuentes. Además, se encontró evidencia clara del transporte local y regional de aerosoles de utilizando el modelo lagrangiano de partículas.
\end{abstract}

\begin{abstract}
The first ever long-term measurement of black carbon $(\mathrm{BC})$ aerosols over an urban location at the central Indo-Gangetic Plain (IGP) is presented. Both short- and long-term variations in BC during the period 2009-2013 are discussed with specific emphasis on variation in $\mathrm{BC}$ sources, meteorology, trend and possible transport pathways across the IGP. High BC mass loading was noted with a 5-yr composite mean ( \pm SD) of 11.8 ( \pm 8.6) $\mu \mathrm{g} \mathrm{m}^{-3}$, having strong and consistent seasonal variations (median: 8.8 ; range: $1.4-48.0 \mu \mathrm{g} \mathrm{m}^{-3}$ ). Winter $\left(21.5 \pm 9.9 \mu \mathrm{gm}^{-3}\right)$ and post-monsoon $\left(17.4 \pm 10.2 \mu \mathrm{g} \mathrm{m}^{-3}\right)$ specific rises in BC mass were consistent with the increase in household emissions, and from agricultural residue burning. The $\mathrm{BC}$ mass concentration was mostly influenced by local sources, while sudden change in $\mathrm{BC}$ was consistent with the change in Delta-C, indicating emissions primarily from biomass burning. Beside sources, atmospheric boundary layer height was noted to considerably influence short-term variations in $\mathrm{BC}$ concentration. A statistically significant monotonic increasing trend in $\mathrm{BC}$ concentration $\left(0.9 \mu \mathrm{g} \mathrm{m}^{-3} \mathrm{yr}^{-1}\right)$ was computed along with its $95 \%$ uncertainty bounds $\left(0.38-1.52 \mu \mathrm{gm}^{-3} \mathrm{yr}^{-1}\right)$. Increase in BC concentration was consistent with a rise in BC sources across the IGP and over India. Furthermore, clear evidence of local and regional scale transport of $\mathrm{BC}$ aerosols was found using the particle Lagrangian model.
\end{abstract}

Keywords: Black carbon, South Asia, Mann-Kendall test, IGP, biomass burning, Delta-C, atmospheric boundary layer. 


\section{Introduction}

Black carbon (BC) aerosols are fine short-lived climate forcers emitted as a result of incomplete combustion of fossil and biomass fuels (Venkataraman et al., 2005; Rehman et al., 2011). Regardless of its short atmospheric lifetime, the strong capacity of absorbing solar radiation makes $\mathrm{BC}$ an extremely important aerosol species, which contributes largely to climate forcing (Ramanathan and Carmichael, 2008; Wang et al., 2014). Several scientific evidences have verified the significant contributions of $\mathrm{BC}$ to global warming (Ramanathan and Carmichael, 2008) and warming in high altitude regions (Menon et al., 2010). Estimates of direct radiative forcing of $\mathrm{BC}$ aerosols vary widely, from 0.19 (Wang et al., 2014) to $0.88 \mathrm{Wm}^{-2}$ (Bond et al., 2013), while the Intergovernmental Panel on Climate Change (Boucher et al., 2013) reports its direct radiative forcing as $0.40 \mathrm{Wm}^{-2}$. Not limited to this, $\mathrm{BC}$ is reported to have effects on the Asian monsoon (Lau et al., 2008; Kumar et al., 2017a), and thereby it has the potential to affect the hydrological cycle and regional food security (Ramanathan and Carmichael, 2008).

Among the dominant sources of $\mathrm{BC}$ aerosols, low temperature combustion of solid biomass fuels for residential cooking and heating purposes contribute to nearly $25 \%$ of the global BC emissions (Bond et al., 2007). These residential biomass-based fuels are the largest contributors of ambient $\mathrm{BC}$ emissions also in the South Asian region (Venkataraman et al., 2005; Banerjee et al., 2017), posing serious threats to human health (Janssen et al., 2011; Kumar et al., 2015a), agriculture and other areas of socio-economic interest (Banerjee et al., 2017). A 60\% sectorial contribution from anthropogenic and $37 \%$ from biomass burning has also been noted over the Bay of Bengal and the Arabian Sea (Kumar et al., 2015b). Fossil fuel-based vehicular emissions (diesel and gasoline) represent another important sectorial emission of BC over this region (Sadavarte and Venkataraman, 2014). This has been the trend over India, East Asia and North America, where local sources contribute almost to 89, 77 and $73 \%$ of the $\mathrm{BC}$ aerosols burden, respectively. This contrasts with the former Soviet Union and Middle Asia, where local sources contribute to $<50 \%$ of the $\mathrm{BC}$ loading, whereas emissions from Europe account almost to $40 \%$ of the BC burden (Zhang et al., 2015). Over South and Southeast Asia, extreme pollution events like agro-residue burning in North
India (Rajput et al., 2014a; Singh et al., 2018), peatland burning (like in central Kalimantan) (Stockwell et al., 2016) and celebratory fireworks over India (Kumar et al., 2016a) emit huge carbonaceous aerosols into the atmosphere. As emitted, $\mathrm{BC}$ aerosols are mostly hydrophobic (Laborde et al., 2013), having relatively shorter residence time ( $<7$ days) (Bond et al., 2013) before gradually mixing with water-soluble components through atmospheric aging, and thereby converting into a hydrophilic compound (Riemer et al., 2010). The aging timescales of BC over East and Southeast Asia, India and North America are in most cases relatively short and remain less than half a day (Wang et al., 2015).

The Indo-Gangetic Plain (IGP) is located in South Asia, covering territories of India, Pakistan and Bangladesh. It has emerged as a global aerosol hotspot with significant emissions of fine aerosols (Mhawish et al., 2017; Singh et al., 2017a, b; Kumar et al., 2018). It is well reported that the entire IGP has a huge aerosol burden, while recent satellite-based observations identified a part of central IGP with elevated fine aerosol concentration, commonly referred as the 'aerosol pool' region (Banerjee et al. 2015; Kumar et al., 2018). Nearly $40-50 \%$ of the total aerosol mass over the IGP is comprised of carbonaceous aerosols (Singh et al., 2017a). The prominent BC sources over IGP are the emissions from conventional fuels (fossil fuels and biofuels), less efficient combustion technologies, household cooking using wood, and a decade-old transport system (Venkataraman et al., 2005; Janssen et al., 2011; Kumar et al., 2015b; Sadavarte and Venkataraman, 2015; Banerjee et al., 2017). The regional meteorology also drives the atmospheric $\mathrm{BC}$ profile by facilitating the transport of the local emissions to a larger distance (Kumar et al., 2015a, b; Murari et al., 2016). The heterogeneity of aerosol properties and $\mathrm{BC}$ sources induces major uncertainties in estimating its climate and health effects. Such uncertainties in $\mathrm{BC}$ dynamics over the central IGP needs detailed investigation on the $\mathrm{BC}$ mass loading, temporal variations and long-term trend.

This article depicts long-term (2009-2013) characteristics of ambient $\mathrm{BC}$ aerosols over an urban location of the IGP. Emphasis was made in understanding the variation of $\mathrm{BC}$ mass concentrations in the context of temporal (both diurnal and seasonal) patterns, influence of local meteorology, especially the atmo- 
spheric boundary layer (ABL), long-range transport, and trend. Documentation of BC emissions, its trend and identification of transport pathways will possibly help to understand BC sources and dynamics over the region. As per our knowledge, such detailed analysis on $\mathrm{BC}$ is reported for the first time over Varanasi. Therefore, it will help to constitute a scientific basis for framing suitable policies to reduce carbonaceous aerosols over this region and will help in evaluating the model outputs for practical applications.

\section{Experimental methods}

\subsection{Site description and general meteorology}

The long-term assessment of ambient $\mathrm{BC}$ aerosols was made for a period of five years (January 2009-December 2013) at Varanasi (Fig. 1). Being located at one of the most fertile flood plains of the world, Varanasi has a huge population (1.6 million) with a density of 9751 inhabitants per $\mathrm{km}^{2}$ (MHA, 2011). The total number of registered vehicles in the city was 588000 until March 2012, with an estimated annual growth of $6 \%$ (MOSPI, 2017a). As one of the important religious centers of India, the city attracts a large amount of tourism and associated anthropogenic activities throughout the year. Along with tourism, Varanasi is also characterized by many small and medium scale industries including silk weaving, metal and power equipment manufacturing, agriculture and animal husbandry within the peripheral areas. Such anthropogenic activities inject significant amounts of pollutants, especially carbonaceous aerosols into the city's environment. The presence of huge carbonaceous aerosols over other locations of the Indo-Gangetic Basin has been previously reported by several researchers (Venkataraman et al., 2005; Kumar et al., 2015b, c). In addition to local sources, the city also experiences a significant load of aerosols via long-range transport (Kumar et al., 2015c, 2018; Sen et al., 2017).

Varanasi $\left(25.16^{\circ} \mathrm{N}, 82.59^{\circ} \mathrm{E}, 77\right.$ masl) typically represents an urban setting with sub-tropical semi-arid climate, having four distinct seasons, i.e. pre-monsoon (March-May), monsoon (June-September), post-monsoon (October-November), and winter (December-February). Meteorological variables, i.e. temperature, wind speed (WS), relative humidity (RH), and visibility obtained from the India Meteorological Department suggest sharp temporal variations. Temperature ranges from $7.0^{\circ} \mathrm{C}$ in winter to $40.0^{\circ} \mathrm{C}$ during the summer, while $\mathrm{RH}$ varies from 15 to $100 \%$. The city receives an annual precipitation of $1100 \mathrm{~mm}$, the majority of which occurs during the monsoon (Murari et al., 2017). Wind over the study site was mainly westerly during summer and winter, and easterly during the monsoon with varying wind speeds. Seasonal means of various meteorological parameters from 2009 to 2013 have been enlisted in Table AI.

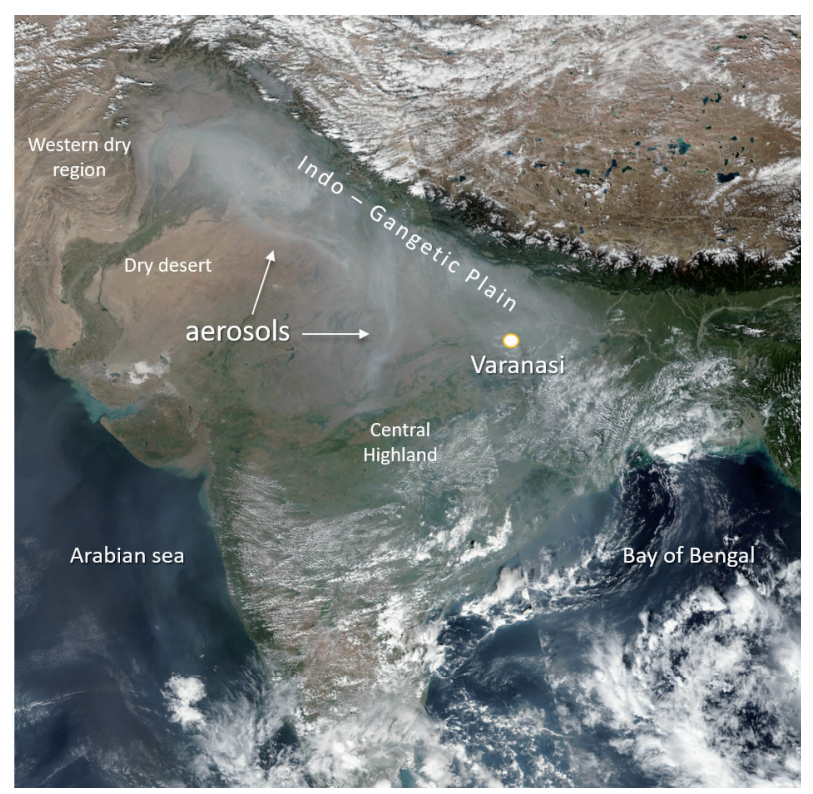

Fig. 1. Geographical location of the $\mathrm{BC}$ aerosol monitoring station. The background image retrieved from the Suomi NPP VIIRS satellite shows the thick aerosol layer over north India on October 31, 2016.

\subsection{Measurements and quality control}

\subsubsection{BC mass concentration}

Real time ambient $\mathrm{BC}$ concentrations were measured using a seven-channel aethalometer (model-AE42, Magee Scientific, USA) from January 2009 to December 2013, at the Banaras Hindu University campus. The aethalometer was kept at an altitude of $25 \mathrm{~m}$ from the ground and measurements were made with a temporal resolution of $5 \mathrm{~min}$. The estimation of $\mathrm{BC}$ mass concentration from the aethalometer is based on the attenuation of light transmitted at seven different wavelengths, i.e. 370, 470, 520, 590, 660, 880 and $950 \mathrm{~nm}$ via its filter tape, on which aerosols 
are deposited through a uniform flow rate. The BC mass concentration corresponding to $370 \mathrm{~nm}$ represents $\mathrm{BC}$ emissions from biomass burning, while $\mathrm{BC}$ measured at the infra-red wavelength $(880 \mathrm{~nm})$ was used to represent both fossil fuel and biomass burning emissions (Wang et al., 2012; Singh et al., 2018). Delta-C was computed as the difference between $\mathrm{BC}_{370}$ and $\mathrm{BC}_{880}$. To interpretate general $\mathrm{BC}$ characteristics, $\mathrm{BC}_{880}$ was followed while $\mathrm{BC}_{370}$ was solely used to compute Delta-C and was not described in general. The range of detection of $\mathrm{BC}$ concentration by the aethalometer was $0-500 \mu \mathrm{g} \mathrm{m}^{-3}$ (resolution: $0.1 \mu \mathrm{g} \mathrm{m}^{-3}$ ) while the uncertainty associated with the measurements was 10\% (Sedlacek, 2016). Further details about the principles for estimating $\mathrm{BC}$ and instrumentation of the aethalometer can be found elsewhere (Sedlacek, 2016).

The rate of change in the attenuation of light is used to estimate the BC mass concentration with Eq. $(1)$, using a specific attenuation cross-section $(\sigma)$ of $16.6 \mathrm{~m}^{2} \mathrm{~g}^{-1}$ :

$\operatorname{ATN}(\lambda)=\sigma(1 / \lambda) \times[\mathrm{BC}]$

where ATN is the attenuation of light of a particular wavelength, $\sigma$ is the specific attenuation and [BC] is the ambient $\mathrm{BC}$ concentration. Theoretically, the increment in attenuation of light varies linearly with $\mathrm{BC}$ mass being deposited on the filter when this is not saturated with particles. However, in the case of extremely high aerosol loadings, high relative humidity and in presence of fresh BC particles, the linearity between attenuation with $\mathrm{BC}$ loadings diminishes due to 'loading effects', resulting into ambiguous estimation of BC mass concentrations. This measurement artifact was removed using an algorithm suggested by Virkkula et al. (2007).

\subsubsection{Air mass trajectories and boundary layer}

Air mass back trajectories, particularly in days with high and low BC mass concentrations, were computed using the Hybrid Single Particle Lagrangian Trajectory (HYSPLIT) model considering archives from the Global Data Assimilation System (GDAS). HYSPLIT (Draxler and Hess, 1998) was run to identify if there was any change in potential emission-source regions during days with high and low $\mathrm{BC}$ concentration. The selection of high and low $\mathrm{BC}$ events was based on the 25th and 75th percentiles of $\mathrm{BC}$ mass concentrations. ABL height was retrieved from GDAS archives from NOAA-Air Resource Laboratory at $0.5^{\circ} \times 0.5^{\circ}$ resolution. ABL was retrieved with a 3-h frequency, which was further averaged over different scales to investigate the role of ABL dynamics.

\subsection{Data analysis and trend estimation}

$\mathrm{BC}$ mass concentrations retrieved at 5-min intervals were initially processed for the removal of outliers and were further averaged on various temporal scales. For estimating monotonic trends in BC aerosol, non-parametric statistical techniques were applied in view of the non-normal distribution of the $\mathrm{BC}$ time series over multiple years. Environmental time series data (here BC) are significantly prone to auto-correlation and seasonality; therefore, prewhitening of $\mathrm{BC}$ time series was made to remove auto-correlation and seasonality using seasonal trend decomposition based on the Loess method. Mann-Kendall trend test and Theil Sen's slope functions were used to visualize and quantify the monotonic trends in the data on annual and seasonal basis. Further details of Mann-Kendall trend and Theil Sen's slope functions may be found elsewhere (Kumar et al., 2018).

\section{Results and discussion}

\subsection{Temporal variations in BC mass}

Considerable variations in 24-h averaged BC concentrations were noted at Varanasi (Fig. 2). The 24-h averaged BC mass concentration from 2009 to 2013 varied from 1.4 to $48.1 \mu^{-3} \mathrm{~m}^{-3}$, with a long-term average $( \pm \mathrm{SD})$ of $11.8( \pm 8.6) \mu \mathrm{g} \mathrm{m}^{-3}$. Extremely high BC mass concentrations over Varanasi in comparison to other South Asian cities (Table I) portray the central IGP as a potential BC hotspot. The sharp temporal variation in $\mathrm{BC}$ concentrations is in line with other aerosol components reported elsewhere (Murari et al., 2015, 2017), depicting substantial inhomogeneity in aerosol chemistry across the region. Owing to the temporal change in emission sources and their relative strengths, such variations in $\mathrm{BC}$ concentration were obvious. Additionally, Varanasi is located downwind to highly polluted urban centers of the IGP, i.e. Lahore (Pakistan), New Delhi, and Kanpur(India). Hence, meteorological interventions 
in BC loadings are apparent on temporal scales mainly due to changing fates of pollutants with varying meteorology.

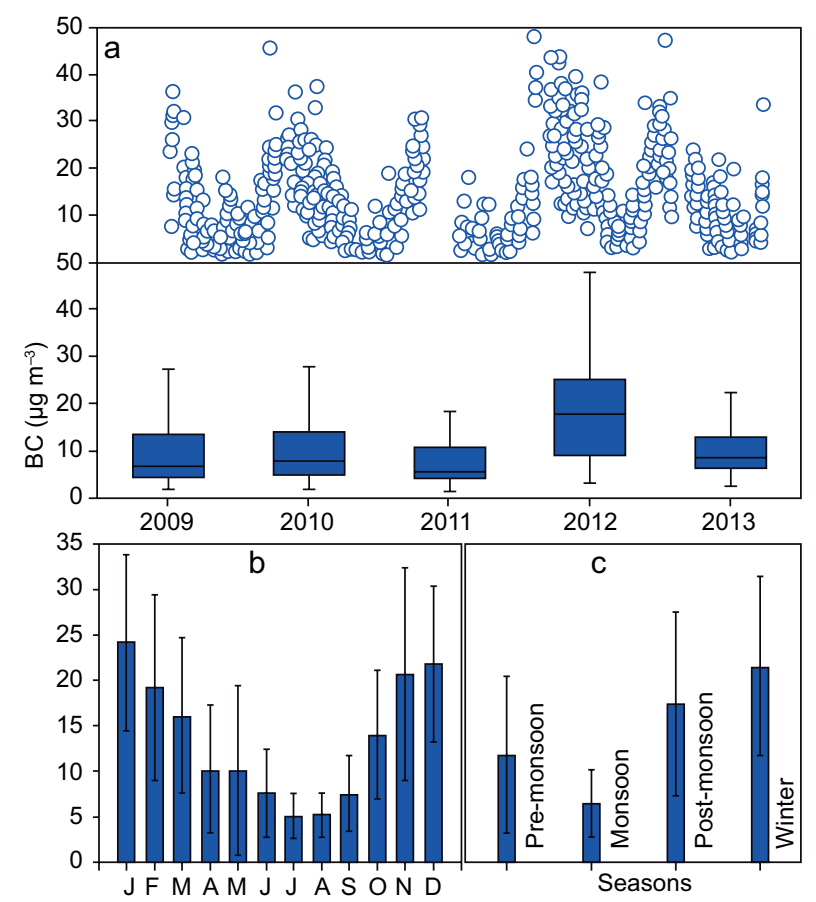

Fig. 2. Time series of $\mathrm{BC}$ mass concentrations at the ground station: (a) annual, (b) monthly, and (c) seasonal.

BC mass concentrations depict a consistent seasonality throughout the study period. Figure 2 represents the seasonal and monthly variations in
BC mass concentrations averaged over 2009-2013. The monthly averaged $\mathrm{BC}$ mass loading revealed high $\mathrm{BC}$ concentrations during winter, i.e. December $\left(21.8 \pm 8.7 \mu \mathrm{g} \mathrm{m}^{-3}\right)$ and January $\left(24.2 \pm 9.7 \mu \mathrm{g} \mathrm{m}^{-3}\right)$, and lower during the monsoon, i.e. July $(5.0 \pm 2.5$ $\left.\mu \mathrm{g} \mathrm{m}^{-3}\right)$ and August $\left(5.2 \pm 2.5 \mu \mathrm{g} \mathrm{m}^{-3}\right)$. The changes in meteorological conditions over the seasons have also been recognized as a key driver in BC dynamics across India (Kumar et al., 2015b). During winter, extremely high loadings of BC aerosols were observed $\left(21.5 \pm 9.9 \mu \mathrm{g} \mathrm{m}^{-3}\right.$, ranging from 4.4-46.8 $\left.\mu \mathrm{g} \mathrm{m}^{-3}\right)$, followed by post-monsoon $(17.4 \pm 10.2$; range: $3.9-48.1 \mu \mathrm{gm}^{-3}$ ). This may be possibly due to an increase in household emissions, like domestic heating and biomass burning, additionally influenced by frequent occurrences of stable atmospheric conditions (Kumar et al., 2017b). Essentially, the burning of paddy residues over northern India and Pakistan during post-monsoon is reported to emit $400 \mathrm{Gg}$ of organic aerosols (OA) and $40 \mathrm{Gg}$ of $\mathrm{BC}$ aerosols (Rajput et al., 2014b), mainly from burning of rice husks (90\%) (Rajput al., 2011; Singh et al., 2017a). There is strong evidence of trans-boundary transport of such huge BC aerosols across the IGP, thereby causing high $\mathrm{BC}$ concentrations in the lower parts of this region (Kumar et al., 2015c, 2017a), which is further discussed in the following section.

Monsoon $\left(6.4 \pm 3.8 \mu \mathrm{g} \mathrm{m}^{-3}\right)$ and pre-monsoon $\left(11.8 \pm 8.7 \mu \mathrm{g} \mathrm{m}^{-3}\right)$ seasons exhibited a comparatively weak $\mathrm{BC}$ mass concentration, mainly due to incidences of wet deposition and higher convective turbulence. Increase in the ABL also facilitates the dispersion of fine mode $\mathrm{BC}$ aerosols. Alike the

Table I. BC mass loadings over different locations of South Asia.

\begin{tabular}{llcrrl}
\hline \multirow{2}{*}{ Station } & Period of study & \multicolumn{4}{c}{$\mathrm{BC}\left(\mu \mathrm{g} \mathrm{m}^{-3}\right)$} \\
\cline { 3 - 5 } & & Minimum & Average & Maximum & \\
\hline Varanasi & January 2009-December 2013 & 1.4 & $11.8 \pm 8.6$ & 48.1 & Present study \\
Varanasi & June-September (2009-2011) & 3.2 & $5.5 \pm 1.1$ & 8.8 & Kumar et al., 2017a \\
Varanasi & October-December 2016 & 2.0 & $8.3 \pm 2.9$ & 15.4 & Singh et al., 2018 \\
New Delhi & August 2010-July 2011 & 0.9 & $6.7 \pm 5.7$ & 25.5 & Tiwari et al., 2013 \\
Kharagpur & December 2009 & 26 & 36.0 & 51 & Pani and Verma, 2014 \\
Kharagpur & April 2010 & 3.3 & 4.4 & 6.3 & Pani and Verma, 2014 \\
Patna & January 2015-December 2015 & 0.06 & $9.1 \pm 3.5$ & 28.6 & Arif et al., 2018 \\
Kathmandu & February 2013-January 2014 & 2.5 & $11.6 \pm 10.7$ & 20.0 & Putero et al., 2015 \\
Colombo & May 2000- December 2005 & - & $11.3 \pm 3.6$ & 23.4 & Seneviratne et al., 2011 \\
Karachi & April 2006-April 2007 & 1.0 & - & 15.0 & Dutkiewicz et al., 2009 \\
\hline
\end{tabular}


post-monsoon, the pre-monsoon season experiences agro-residues burning, especially wheat residues (Rajput et al., 2014a). However, weaker BC loadings during the pre-monsoon were possibly due to unstable meteorological conditions, which disperse $\mathrm{BC}$ aerosols both horizontally and vertically. Wind also governs the BC distribution (Putero et al., 2015) and has a major role in dispersing $\mathrm{BC}$ during the pre-monsoon season. Monsoon-specific low BC concentration are mainly driven by relative humidity and precipitation, which helps to the agglomeration of finer particles and their subsequent wet deposition. The relative contributions of specific meteorological variables to BC mass loadings are further developed in the following sections.

\subsection{Distribution of BC mass}

The frequency of $\mathrm{BC}$ mass concentrations indicate a strong seasonality in BC observational ranges (Fig. 3). The annual frequency distribution highlights the dominance of $\mathrm{BC}$ in $\leq 10 \mu \mathrm{g} \mathrm{m}^{-3}$, accounting for $55 \%$ of the total observations, the majority of which fall within the range of $5-10 \mu \mathrm{g} \mathrm{m}^{-3}(31 \%)$. The low range of BC concentrations $\left(\leq 10 \mu \mathrm{g} \mathrm{m}^{-3}\right)$ mainly prevailed during the pre-monsoon and monsoon seasons, accounted for $56 \%$ and $87 \%$ of the season-specific values, respectively. In contrast, only few incidences of low BC loadings $\left(<10 \mu \mathrm{g} \mathrm{m}^{-3}\right)$ were evident during the post-monsoon (21\%) and winter (9\%). Additionally, during the non-polluted seasons (summer and monsoon), larger frequencies were only observed for small concentration bins while, in polluted seasons (post-monsoon and winter), larger frequencies were noted in high concentration bins. Likewise, in the pre-monsoon, the majority of the $\mathrm{BC}$ concentration remain within $5-10 \mu \mathrm{g} \mathrm{m}^{-3}$, while in monsoon, $\mathrm{BC}$ mainly persists $<5 \mu \mathrm{g} \mathrm{m}^{-3}(45 \%)$. Nevertheless, some specific incidences of high BC concentrations $\left(15-20 \mu \mathrm{g} \mathrm{m}^{-3}\right)$ were also evident during the pre-monsoon $(15 \%)$, referring auxiliary effects of local emissions and transported BC from upper IGP during the wheat residue burning period (Kumar et al., 2016b). However, extremely high BC values $\left(\geq 20 \mu \mathrm{g} \mathrm{m}^{-3}\right.$ ) were only noted during post-monsoon $(34 \%)$ and winter $(57 \%)$, consistent with the general $\mathrm{BC}$ observations over the region (Udayasoorian et al., 2014). Likewise, during winter, $27 \%$ of the $B C$ observations were in the range of $20-25 \mu \mathrm{g} \mathrm{m}^{-3}$, while concentrations exceed $30 \mu \mathrm{g} \mathrm{m}^{-3}$ in $6 \%$ of days.
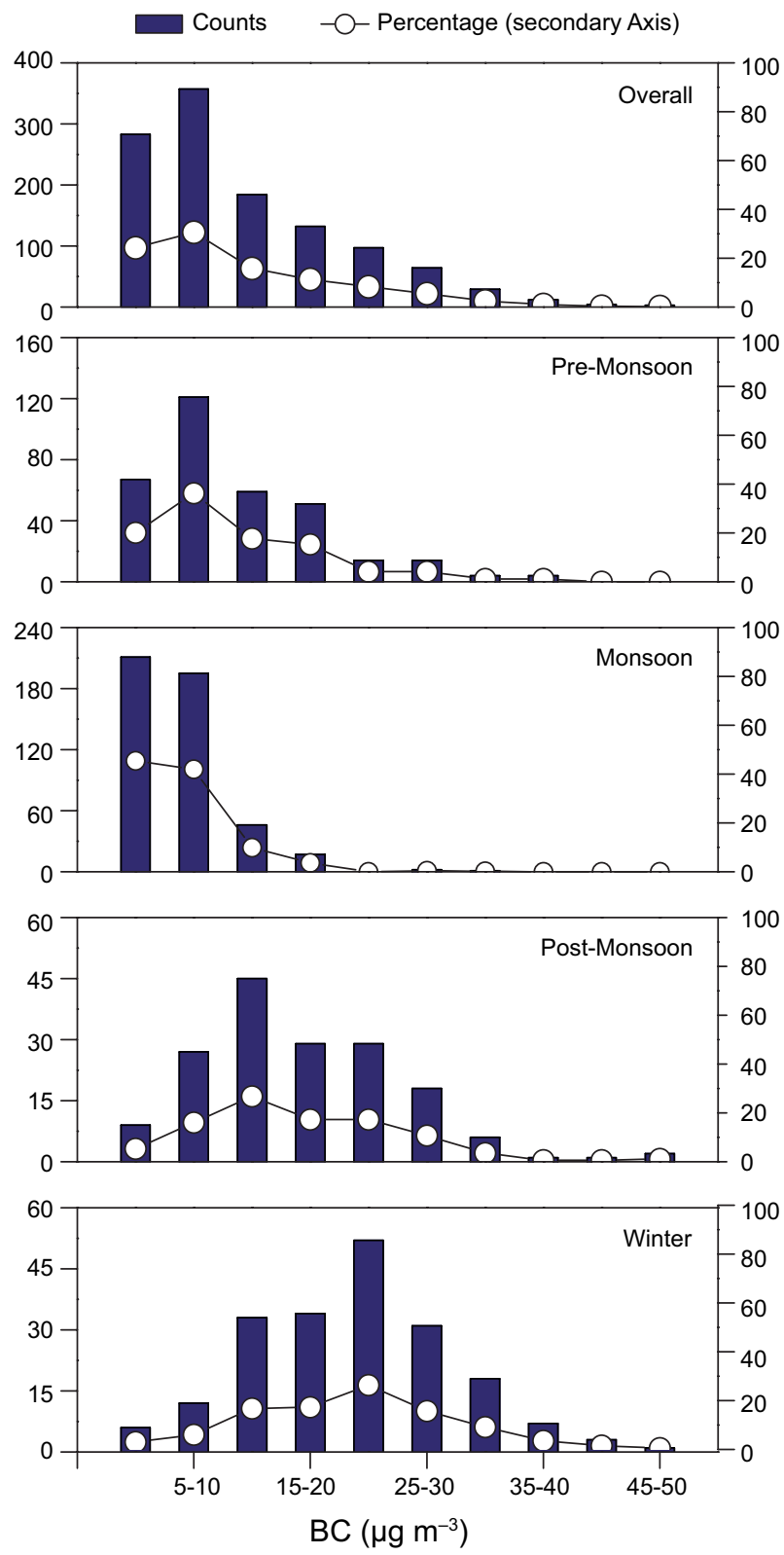

Fig. 3. Frequency distribution of BC mass loadings representing high temporal heterogeneity.

\subsection{Diurnal variation of $B C$ aerosols}

Diurnal variation of $\mathrm{BC}$ aerosols averaged over 5 yrs was typically bimodal, consisting of two isolated peaks, i.e. one during the early-morning (06:00-08:00 LT) and the other during evening hours (22:00-00:00 LT; Fig. 4). However, the extent of peaks during morning and evening hours differs, with higher magnitude during the 
evening hours irrespective of seasons. Fig. 4 also includes BC diurnal variations for the respective seasons anticipating different mechanisms of BC dynamics. The initial rise in $\mathrm{BC}$ concentrations began just at sunrise (05:00-06:00 LT), achieving its maximum at 07:00-09:00 h (16 \pm $\left.9 \mu \mathrm{g} \mathrm{m}^{-3}\right)$ before decreasing at 14:00-16:00 h $(5 \pm$ $\left.3 \mu \mathrm{g} \mathrm{m}^{-3}\right)$. The entrainment of $\mathrm{BC}$ nocturnal residuals starts during early morning hours, leading to an augmented BC concentration only during a few hours. This phenomenon, commonly referred as 'fumigation effect', coupled with other anthropogenic emissions during early rush hours (mainly cooking, commuting etc.), is responsible for initial BC peaks. A further rise in temperature during daytime leads to a deepening of the $\mathrm{ABL}$ height and the consequent dilution of $\mathrm{BC}$ particles to its minimum concentration $\left(5 \pm 2 \mu \mathrm{g} \mathrm{m}^{-3}\right)$. With the sunset, the second peak in $\mathrm{BC}$ concentration merge with the evening traffic rush hours (17:00-20:00 LT). However, the BC concentration continues to rise and reaches its maximum at 23:00 h $\left(20 \pm 12 \mu \mathrm{g} \mathrm{m}^{-3}\right)$, mainly due to restricted vertical mixing of the prevailing air mass. The diurnal variations of $\mathrm{BC}$ concentrations are highly region-specific, having specific signatures of region-
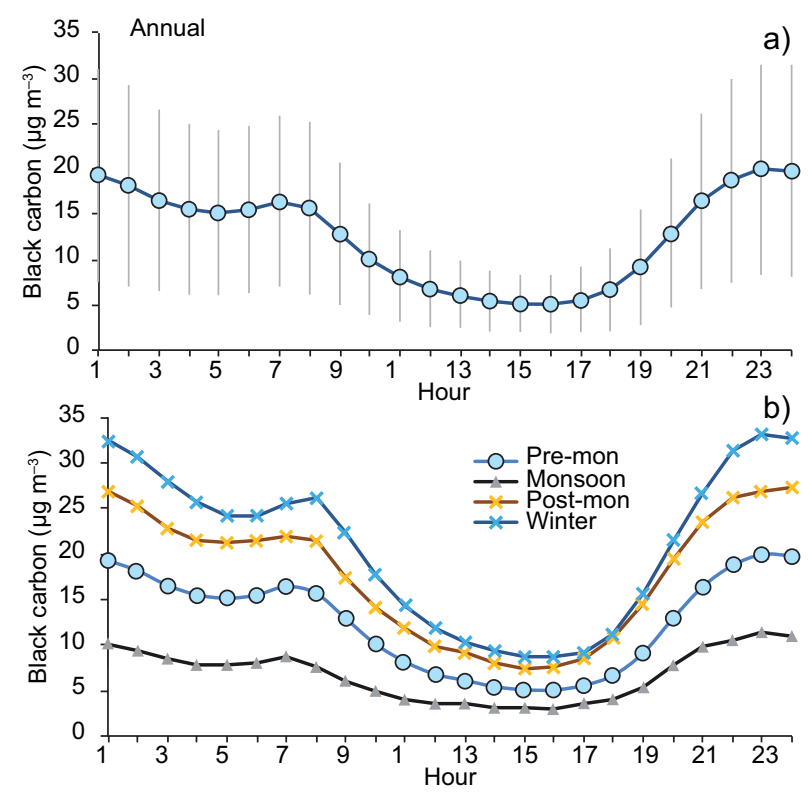

Fig. 4. Diurnal variations of BC over the study site: (a) annual (b) seasonal. al emissions and meteorological conditions. Highly variable BC dynamics were also reported over different locations across South Asia, particularly over Karachi (Dutkiewicz et al., 2009), Lahore (Husain et al., 2007), and Kathmandu (Putero et al., 2015), highlighting different profiles in $\mathrm{BC}$ concentrations across the seasons.

Diurnal variations of the $\mathrm{BC}$ aerosol mass are also plotted in Figure 4 for individual season averages from 2009 to 2013. The night-to-day $\mathrm{BC}$ ratio varied from 1.8 to 2.1 (mean $\pm \mathrm{SD}$ : $1.89 \pm 0.09)$, with ratios $>2.0$ mainly from $\mathrm{Au}-$ gust to November. There was strong inter-seasonal deviation in $\mathrm{BC}$ mass, most significantly during the post-monsoon (day: $12 \pm 2$; night: 23 $\left.\pm 1 \mu \mathrm{gm}^{-3}\right)$ and winter $\left(15 \pm 1 ; 27 \pm 2 \mu \mathrm{g} \mathrm{m}^{-3}\right)$ compared to pre-monsoon $\left(7 \pm 2 ; 14 \pm 2 \mu \mathrm{g} \mathrm{m}^{-3}\right)$ and monsoon $\left(5 \pm 1 ; 9 \pm 1 \mu \mathrm{g} \mathrm{m}^{-3}\right)$. Irrespective of the seasons, greater daytime fluctuations in BC mass concentrations $\left(8.6-30.5 \mu \mathrm{g} \mathrm{m}^{-3}\right)$ were also noted compared to nighttime $\left(6.2-17.8 \mu \mathrm{g} \mathrm{m}^{-3}\right)$, which may be influenced by periodicity in household, transport activities and local convective processes.

\subsection{Impact of the atmospheric boundary layer and local meteorology on $B C$ aerosols}

The influence of the ABL on temporal and diurnal variations of $\mathrm{BC}$ mass was further investigated. Figure 5a shows the variations in monthly averaged ABL heights with $\mathrm{BC}$ loadings averaged over the entire study period.

An inverse relation between ABL height and $\mathrm{BC}$ mass concentration was noted throughout the monitoring period. ABL height ranged from $307 \mathrm{~m}$ in December to $2100 \mathrm{~m}$ in May, with annual average ( \pm SD) of $794 \mathrm{~m}(207 \mathrm{~m})$. Seasonal observations depicted extremely shallower ABL heights, as low as $390 \pm 77 \mathrm{~m}$ during winter, while it was quite deeper during the pre-monsoon season $(1295 \pm 384$ $\mathrm{m})$. High BC concentrations in winter $(21.5 \pm 9.9$ $\left.\mu \mathrm{g} \mathrm{m}^{-3}\right)$ and post-monsoon $\left(17.4 \pm 10.2 \mu \mathrm{g} \mathrm{m}^{-3}\right)$ are in good correspondence with their lowest $\mathrm{ABL}$ heights, indicating minimal ambient mixing of $\mathrm{BC}$ in comparison to pre-monsoon $\left(11.8 \pm 8.7 \mu \mathrm{g} \mathrm{m}^{-3}\right)$ and monsoon seasons $\left(6.4 \pm 3.8 \mu \mathrm{g} \mathrm{m}^{-3}\right)$. Ambient BC mass concentrations and $\mathrm{ABL}$ heights reflected the negative correlation between the two variables $(r=$ -0.25 ), varying considerably across seasons. 


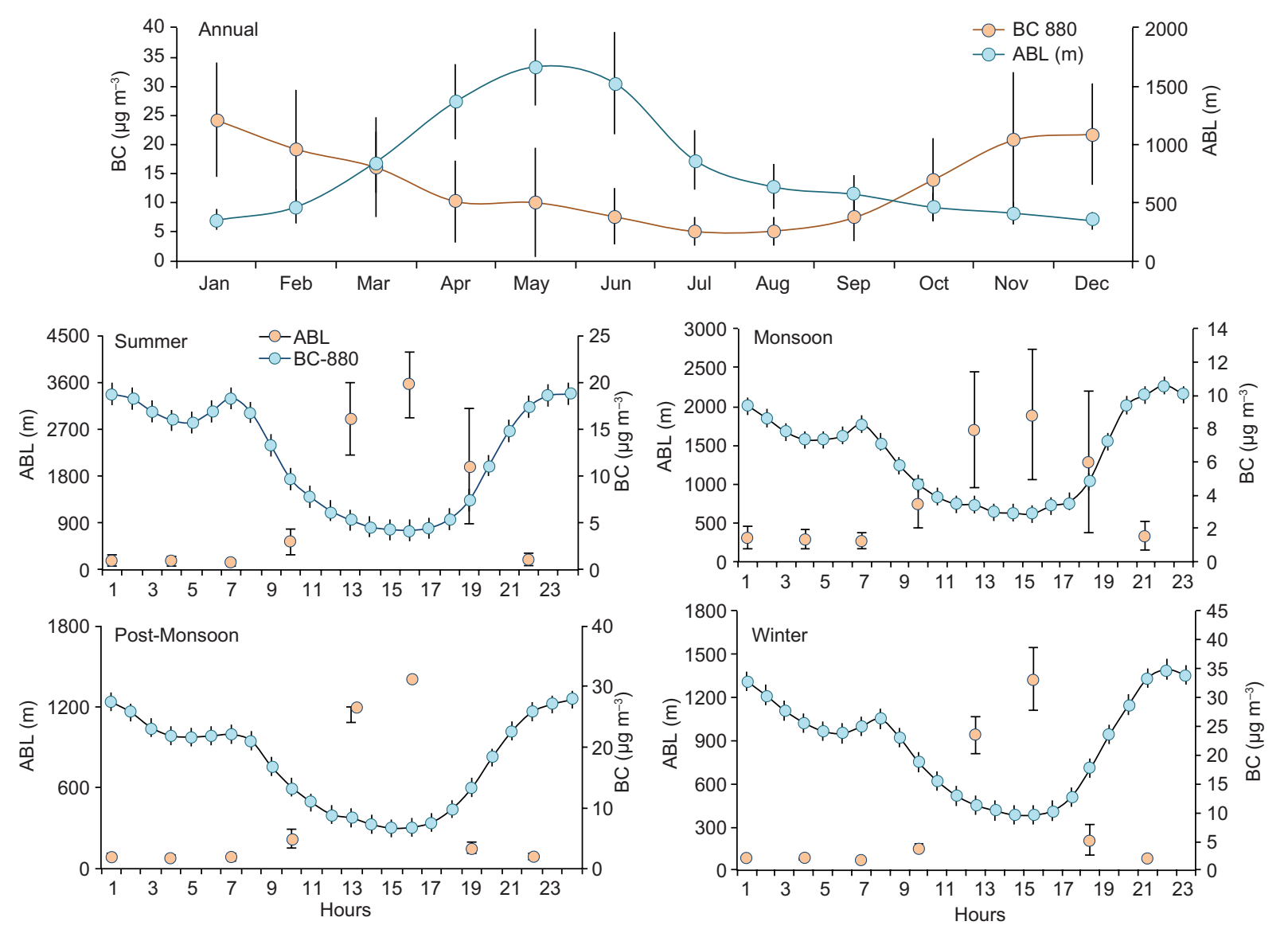

Fig. 5. (a) Annual and (b) seasonal variation of BC in reference to boundary layer height.

The influence of boundary layer dynamics on BC loadings was also evaluated for individual seasons on a diurnal scale (Fig. 5b). Diurnal cycles of both BC and $\mathrm{ABL}$ heights were found negatively associated, showing highest nocturnal $\mathrm{BC}$ concentrations (5-yr nighttime $\mathrm{BC}$ average: $27.2 \pm 1.59 \mu \mathrm{g} \mathrm{m}^{-3}$ ) when ABL height was minimum (nighttime ABL: $388 \pm 633$ $\mathrm{m}$ ) and vice-versa (daytime $\mathrm{BC}: 14.6 \pm 1.05 \mu \mathrm{g} \mathrm{m}^{-3}$; daytime ABL: $1104 \pm 1092 \mathrm{~m}$ ). The diurnal variation in BC loadings observed over central IGP with elevated nocturnal peaks clearly highlighted the foremost role of $\mathrm{ABL}$ in regulating $\mathrm{BC}$ mass concentrations. The influence of ABL height on BC dynamics was consistent across the seasons. This suggest a stronger impact of boundary layer on the diurnal variations of $\mathrm{BC}$ aerosols in comparison to their seasonal behavior, which is mostly affected by the variation in $\mathrm{BC}$ source strengths and long-range transport of $\mathrm{BC}$ aerosols

\subsection{Source characterization and long-range trans-} port

In comparison to long-lived greenhouse gases, the residence time of $\mathrm{BC}$ aerosols is relatively short and is mainly influenced by meteorology and the geographical region (Liu et al., 2011). There have been significant uncertainties in horizontal and vertical distribution of $\mathrm{BC}$ aerosols, which cause uncertainties in $\mathrm{BC}$-induced radiative forcing. Multi-fold increase in direct radiative forcing efficiency of $\mathrm{BC}$ has been reported with increase in altitude, which is in contrast with the reduction in semi-direct effects. Still, there are evidences of rise in precipitation with increase in near-surface $\mathrm{BC}$ concentrations, while at high altitudes BC is believed to reduce precipitation (Samset and Myhre, 2015). The long-range transport and atmospheric aging of $\mathrm{BC}$ aerosols are also reported to influence its physical property, modifying it from 
hydrophobic (as emitted) to hydrophilic aerosols (coated with water-soluble components). This significantly impacts the $\mathrm{BC}$ residence time as otherwise $\mathrm{BC}$ aerosols are subject to cloud condensation nuclei and are readily scavenged from the atmosphere (Riemer et al., 2010; Singh et al., 2017a).

Long-range transport of BC aerosols is often reported as a significant contributor to local concentration, primarily from Asia to north Pacific, South America to southwest Atlantic (Evangelista et al., 2007), and eastern and central Asia to oceans over the Northern Hemisphere (Kaneyasu and Murayama, 2000). Over India, only local sources (89\%) were however reported to influence $\mathrm{BC}$ concentrations (Zhang et al., 2015), while there are few evidences that indicate episode-specific contributions of transboundary aerosols over the IGP (Kumar et al., 2015b, 2017a). Considering such hypothesis and uncertainties, longrange transport of $\mathrm{BC}$ aerosols across the IGP were mapped contemplating two possible scenarios: days with high BC mass concentration $\left(>27 \mu \mathrm{g} \mathrm{m}^{-3}\right.$, fourth quartile), and days with low $\mathrm{BC}$ mass concentration $\left(<4 \mu \mathrm{g} \mathrm{m}^{-3}\right.$, fourth quartile) (Fig. 6).

To establish the influence of regional transport of air masses, seven-day isentropic air-mass back trajectories at varying altitudes were also calculated (Fig. A1). This potentially serves as an indicator of the BC source regions and its transport. Back trajectory analysis revealed an overall contribution from both marine and continental aerosols, although to a different extent. Interestingly, at a lower altitude
(125 masl, Fig. 6), days with relatively high BC concentration were only found to be influenced by air-masses originating from the upper IGP, especially from northern parts of Pakistan, the Indian state of Punjab and Haryana, and from the western semi-arid region. This is consistent with the increase in altitude $(1000$ and $1500 \mathrm{~m})$, with additional influence of long-range transport from western semi-arid regions of Pakistan, central eastern Asia, and western dry regions of India (Fig. A1). Further, most cases of high BC loadings fall within the months of October to January, coinciding well with the dominating biomass burning period. In contrast, days with low $\mathrm{BC}$ mass concentrations indicate the dominance of continental air masses (from the central highlands, Deccan plateau, and the southern peninsular region) and marine air masses (from the Bay of Bengal and the Arabian Sea), without having any specific influence from the upper IGP. It should be noted that we only considered regional air-masses as a proxy for BC aerosol transport across the IGP; however, a detailed sensitivity simulation using global chemical transport model is under process. The distinction in air mass origin between days with high and low BC concentrations was prominent, providing clear evidence of the contribution of sources from the upper IGP to the local $\mathrm{BC}$ concentrations.

\section{6 Long-term trend in BC aerosol}

India's fast-growing economy based on manufacturers and service industries resulted into a massive
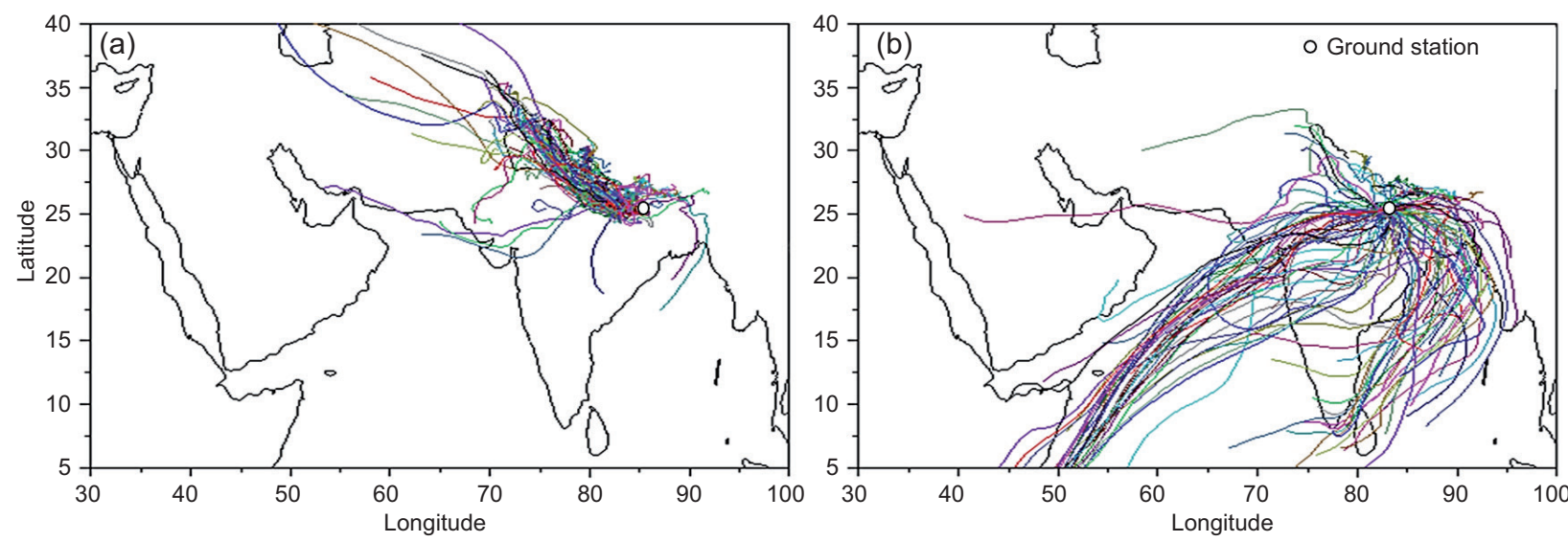

Fig. 6. HYSPLIT seven-days backward trajectories at 125 masl for (a) very high and (b) very low BC loading days (different trajectory colors indicate different BC monitoring days). 
growth of $\mathrm{BC}$ emissions during the $1990 \mathrm{~s}$, with the IGP as the major regional source. In their estimate for the period 1960-2007, Wang et al. (2014) state that the growth of energy in India was projected to be higher (4\% per year) in comparison to BC emissions ( $2 \%$ per year). Emissions of BC were also estimated to increase by $49 \%$ collectively from industry, transport, residential and agricultural sources from 2005-2015 (Pandey et al., 2014; Sadavarte and Venkataraman, 2015) and is projected to be doubled by 2030. Exceptional increase in coal and petroleum consumption within the last three decades coupled with emissions from biofuel-based energy mainly facilitate the increase in $\mathrm{BC}$ concentration.

Considering all these projections, the long-term (2009-2013) monotonic trend in BC mass concentration was evaluated using non-parametric statistics. Figure 7 shows the monotonic trend in a pre-whitened de-seasonalized annual BC time series, while within-season trends were plotted using a standard MK test. The long-term semi-decadal trend in BC mass concentration shows a statistically significant
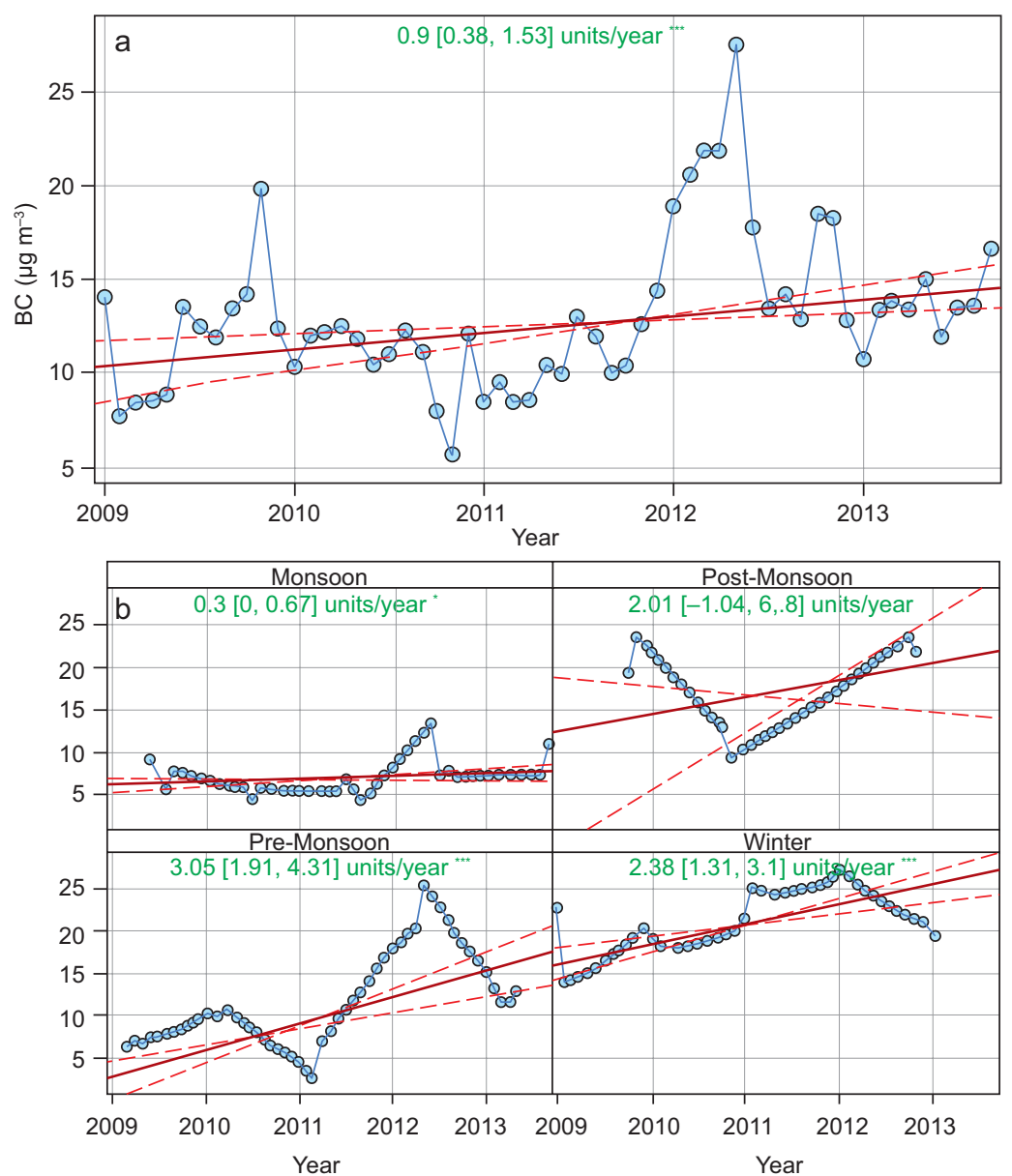

Fig. 7. Long-term trend in $\mathrm{BC}$ mass concentration. (a) Annual and (b) seasonal. The plot shows 5-yr trends in BC over the ground-monitoring station at Varanasi.. The blue line represents the monthly averaged aerosol optical depth time series. The solid red line shows the trend estimate and the dashed red lines show the $95 \%$ confidence intervals for the trend based on resampling methods. The overall trend is shown in green as unit per year, and the values inside the brackets denote the $95 \%$ confidence interval limits. 
increase in BC mass concentration $\left(0.9 \mu \mathrm{g} \mathrm{m}^{-3} \mathrm{y}^{-1}\right)$ within $95 \%$ uncertainty bounds of $0.38-1.52 \mu \mathrm{g}$ $\mathrm{m}^{-3} \mathrm{y}^{-1}$. On a closer observation of estimates, it was found that the $\mathrm{BC}$ trend was steeper during the later phase of the study (2011-2013) compared to the initial period. Since the majority of emission estimates over India are based on bottom-up approach (Sadavarte and Venkataraman, 2015), evaluation of key BC sources and their generalized emission budget may well be useful to understand $\mathrm{BC}$ emissions and its trend over a region. Increase in Indian energy consumption in terms of coal (2009-2013: $24 \%)$, crude petroleum oil (19\%), natural gas (1\%) (MOSPI, 2017b) as well as per capita consumption of petroleum products over the Indian state of Uttar Pradesh (7\%) (MPNG, 2016) highlights the possibility of carbonaceous aerosol emission (Table AII). Beside, a 9\% growth in urbanization exclusively over Uttar Pradesh (MUD, 2016) was also consistent with the increase in BC emission. Additionally, a $77 \%$ increase in the number of register vehicles over Uttar Pradesh may be used as a proxy for BC emissions and justify the increasing trend in $\mathrm{BC}$ aerosols.

Considering the significant temporal heterogeneity of sources and the strengths of carbonaceous aerosols, the trend of $\mathrm{BC}$ aerosols was further classified into seasons (Fig. 7b). Seasonal estimates also resemble the annual increasing trend. Significant increase in BC emission during winter $\left(2 \mu \mathrm{g} \mathrm{m}^{-3} \mathrm{y}^{-1}\right)$ and in pre-monsoon $\left(3.0 \mu \mathrm{g} \mathrm{m}^{-3} \mathrm{Y}^{-1}\right)$ depicts the high season specific contribution. The high pre-monsoon specific trend is possibly related to massive emission of wheat residue burning, coupled with recent decline in winter monsoon rainfall. There was insignificant increasing trend during post-monsoon $\left(2.0 \mu \mathrm{g} \mathrm{m}^{-3}\right.$ $\left.\mathrm{Y}^{-1}\right)$, while $\mathrm{BC}$ trend during monsoon was feebly significant $\left(0.3 \mu \mathrm{g} \mathrm{m}^{-3}\right.$ per $\left.\mathrm{Y}^{-1}\right)$. The long-term trend estimates over central IGP clearly define the relative contribution of seasonal BC sources and therefore, require proper addressing both in terms of policy and scientific levels.

\subsection{Spectral dependence of $B C$ aerosols}

To account for the temporal variation of BC sources, we assumed that the attenuation of radiation by aerosols at different wavelengths is mainly influenced by different kind of carbonaceous particles.
Considering the spectral dependence of carbonaceous aerosols, BC measured at UV range $(370 \mathrm{~nm})$ was used as representative of biomass burning emissions, while BC measured at infrared range $(880 \mathrm{~nm})$ was used to represent both fossil fuel and biomass burning emissions (Wang et al., 2012; Singh et al., 2018). Such assumptions have scientific ground, as organic aerosols emitted from biomass burning emissions have higher absorption at UV range than in infrared. The difference between both, i.e. Delta-C, is reported to symbolize $\mathrm{BC}$ emissions mainly from biomass burning (Wang et al., 2012; Kumar et al., 2016a). To understand the variation in $\mathrm{BC}$ sources, monthly averages of Delta-C concentration (mean \pm SD: $5.4 \pm$ $3.1 \mu \mathrm{g} \mathrm{m}^{-3}$ ) is included in Fig. 8, which also shows a temporal shift in BC sources. Invariably, the highest Delta-C values were noted in December (12.7 $\left.\pm 8.0 \mu \mathrm{g} \mathrm{m}^{-3}\right)$ and January $\left(11.0 \pm 5.1 \mu \mathrm{g} \mathrm{m}^{-3}\right)$, followed by November $\left(10.7 \pm 6.1 \mu \mathrm{g} \mathrm{m}^{-3}\right)$. Characteristically, all the high Delta-C values $\left(>7 \mu \mathrm{g} \mathrm{m}^{-3}\right)$ were noted only from October to February, which exhibits the predominant contributions of biomass burning emissions. As expected, a strong seasonality was also noted with higher Delta-C values, particularly in winter (seasonal mean: $10.4 \mu \mathrm{g} \mathrm{m}^{-3}$ ) while lower values were observed during summer months $\left(2.1 \mu \mathrm{g} \mathrm{m}^{-3}\right)$.

The diurnal variation in Delta-C was mostly consistent with the $\mathrm{BC}_{880 \mathrm{~nm}}$ profile, having a bimodal peak, one at 08:00 LT $\left(9.3 \mu \mathrm{g} \mathrm{m}^{-3}\right)$ and the next one at 22:00 LT $\left(11.6 \mu \mathrm{gm}^{-3}\right)$. Both peaks correspond to an increase in anthropogenic emissions, particularly from vehicular emissions. This lead us to conclude with reasonable confidence that $\mathrm{BC}$ dynamics over the middle IGP are mostly regulated by anthropogenic emissions from local sources, mainly emissions from fossil fuel combustion and residential emissions, while biomass burning emissions during winter and post-monsoon, and the contribution from long-range transport (primarily from the upper IGP), also have considerable influence on local BC concentrations. Therefore, we strongly suggest that both long-range transport of $\mathrm{BC}$ and inter-seasonal variations of $\mathrm{BC}$ sources are necessary in regional climate and air quality modeling to improve the parameterization of $\mathrm{BC}$ aerosols. 

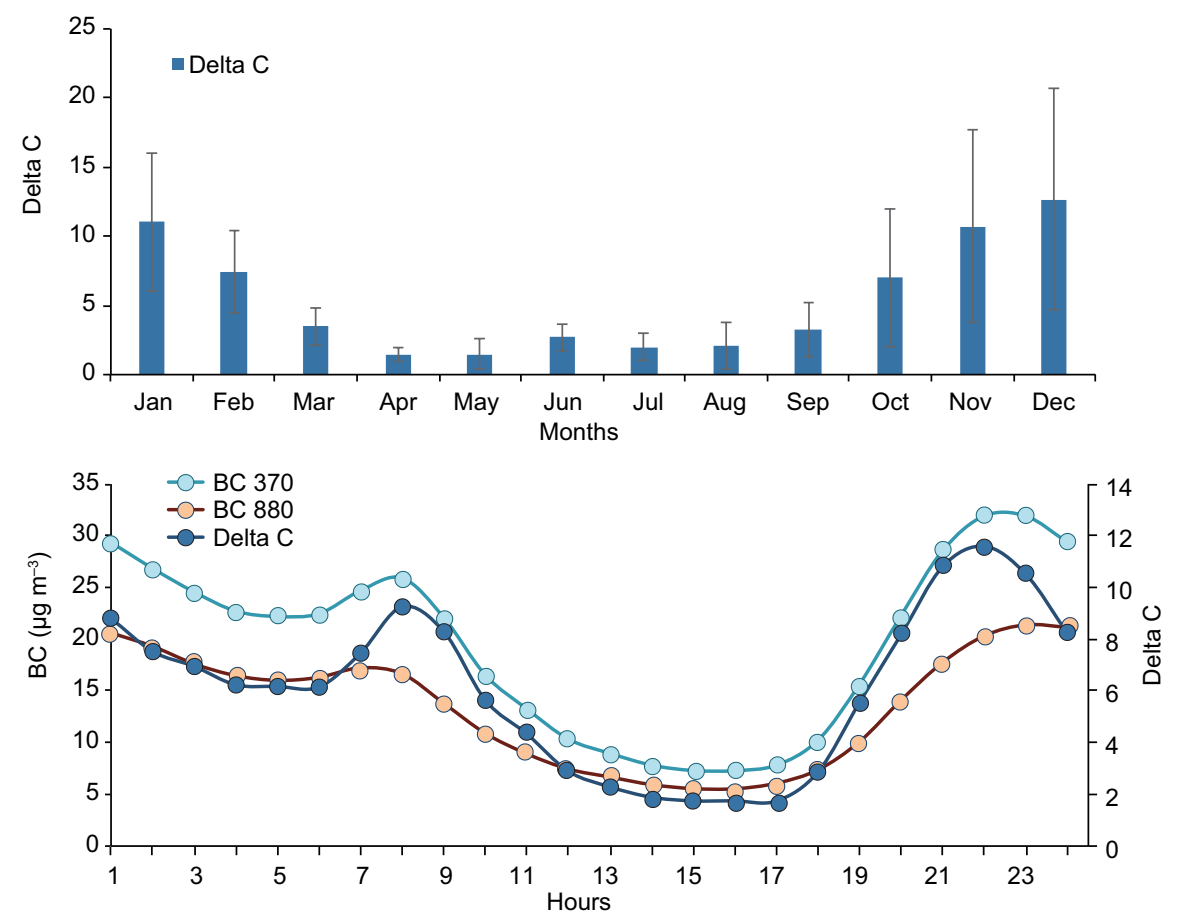

Fig. 8. Temporal variation of Delta-C $\left(\mu \mathrm{g} \mathrm{m}^{-3}\right)$. (a) Monthly and (b) diurnal variation.

\section{Conclusions}

The first ever long-term measurements of BC aerosols over Varanasi, in the middle IGP are presented. Discussions are made considering variations in $\mathrm{BC}$ sources, local meteorology, trends and a possible transport mechanism across the IGP. Some specific findings are briefed:

A considerable variation in 24-h mean BC concentrations was noted, primarily influenced by regional/ local sources and regional meteorology. A consistent seasonality in $\mathrm{BC}$ concentrations was also noted with high $\mathrm{BC}$ aerosol loadings during winter, followed by the post-monsoon.

The diurnal variations of $\mathrm{BC}$ aerosols were typically bimodal, including two specific peaks, one at morning hours (06:00-08:00 LT) and other at evening hours (22:00-00:00 LT). In both cases, local sources and boundary layer heights were found to influence the $\mathrm{BC}$ diurnal variation.

Characteristic seasonal and diurnal responses of $\mathrm{BC}$ aerosols to atmospheric boundary layer dynamics were also noted. An inverse relation of BC mass loadings with $\mathrm{ABL}$ heights persisted throughout the year, although more prominently for diurnal cycle compared to the seasonal cycle.

The diurnal $\mathrm{BC}$ profile was found mainly governed by the ABL height while seasonal variations in $\mathrm{BC}$ mass was in function both to source strengths and aerosol long-range transport.

The long-range transport potential of $\mathrm{BC}$ aerosols across the IGP was also mapped considering two possible scenarios: days with high $\mathrm{BC}$ loading and days with low BC mass. At lower altitudes, air-masses originating from the upper IGP, northern parts of Pakistan, the Indian state of Punjab and Haryana, as well as the western semi-arid region, were found to influence local $\mathrm{BC}$ concentrations during high $\mathrm{BC}$ loading days. In contrast, winds from central India and marine winds were found to influence local BC concentrations during low-loading days.

The long-term trend in $\mathrm{BC}$ mass concentration refers to a statistically significant increasing trend, well consistent with regional rise in potential BC sources.

Relatively high Delta-C values during post-monsoon and winter indicate predominant emissions from biomass burning. 


\section{Acknowledgments}

Atmospheric black carbon BC was monitored under the Aerosol Radiative Forcing over India (ARFI) scheme (code P-32-13) financed by the Indian Space Research Organization, Thiruvananthapuram. MK acknowledges the Council for Scientific and Industrial Research (CSIR) for a senior research fellowship. Meteorological data were courtesy of IMD-Varanasi and wunderground.com. Authors are thankful to the director, IESD-BHU and dean, FESD-BHU for all the support.

\section{References}

Arif M., Kumar R., Kumar R., Zusman E., Singh R.P. and Gupta A., 2018. Assessment of indoor \& outdoor black carbon emissions in rural areas of Indo-Gangetic Plain: Seasonal characteristics, source apportionment and radiative forcing. Atmos. Environ. 191, 227-240.

DOI: 10.1016/j.atmosenv.2018.07.057

Banerjee T., Murari V., Kumar M. and Raju M.P., 2015. Source apportionment of airborne particulates through receptor modeling: Indian scenario. Atmos. Res. 164, 167-187. DOI: 10.1016/j.atmosres.2015.04.017

Banerjee T., Kumar M., Mall R.K. and Singh R.S., 2017. Airing 'clean air' in clean India mission. Environ. Sci. Pollut. Res. 24, 6399-6413.

DOI: $10.1007 / \mathrm{s} 11356-016-8264-\mathrm{y}$.

Bond T.C., Bhardwaj E., Dong R., Jogani R., Jung S., Roden C., Streets D.G. and Trautmann N.M., 2007. Historical emissions of black and organic carbon aerosol from energy-related combustion, 1850-2000. Global Biogeochem. Cy. 21, GB2018.

DOI: $10.1029 / 2006$ GB002840

Bond T.C., Doherty S.J., Fahey D.W., Forster P.M., Berntsen T., DeAngelo B.J., Flanner M.G., Ghan S., Kärcher B., Koch D. and Kinne S., 2013. Bounding the role of black carbon in the climate system: A scientific assessment. J. Geophys. Res.-Atmos. 118, 5380-5552. DOI: 10.1002/jgrd.50171

Dutkiewicz V.A., Alvi S., Ghauri B.M., Choudhary M.I. and Husain L., 2009. Black carbon aerosols in urban air in South Asia. Atmos. Environ. 43, 1737-1744. DOI: 10.1016/j.atmosenv.2008.12.043

Draxler R.R. and Hess G.D., 1998. An overview of the HYSPLIT_4 modelling system for trajectories. Aust. Meteorol. Mag. 47, 295-308.
Evangelista H., Maldonado J., Godoi R.H.M., Pereira E.B., Koch D., Tanizaki-Fonseca K., van Grieken R., Sampaio M., Setzer A., Alencar A. and Gonçalves S.C., 2007. Sources and transport of urban and biomass burning aerosol black carbon at the South-West Atlantic Coast. J. Atmos. Chem. 56, 225-238.

DOI: $10.1007 / \mathrm{s} 10874-006-9052-8$

Husain L., Dutkiewicz V.A., Khan A.J. and Ghauri B.M., 2007. Characterization of carbonaceous aerosols in urban air. Atmos. Environ. 41, 6872-6883.

DOI: 10.1016/j.atmosenv.2007.04.037

Janssen N.A., Hoek G., Simic-Lawson M., Fischer P., Van Bree L., Ten Brink H., Keuken M., Atkinson R.W., Anderson H.R., Brunekreef B. and Cassee F.R., 2011. Black carbon as an additional indicator of the adverse health effects of airborne particles compared with $\mathrm{PM}_{10}$ and $\mathrm{PM}_{2.5}$. Environ. Health Persp. 119, 1691-1699. DOI: $10.1289 / \mathrm{ehp} .1003369$

Kaneyasu N. and Murayama S., 2000. High concentrations of black carbon over middle latitudes in the North Pacific Ocean. J. Geophys. Res. Atmos. 105, 1988119890. DOI: 10.1029/2000JD900240

Kumar M., Singh R.S. and Banerjee T., 2015a. Associating airborne particulates and human health: Exploring possibilities. Comment on: Kim, K.-H., Kabir, E. and Kabir, S. 2015. A review on the human health impact of airborne particulate matter. Environment International 74, 136-143. Environ. Inter. 84, 201.

DOI: 10.1016/j.envint.2015.06.002

Kumar R., Barth M.C., Pfister G.G., Nair V.S., Ghude S.D. and Ojha N., 2015b. What controls the seasonal cycle of black carbon aerosols in India? J. Geophys. Res.-Atmos. 120, 7788-7812. DOI: 10.1002/2015JD023298

Kumar M., Tiwari S., Murari V., Singh A.K. and Banerjee T., 2015c. Wintertime characteristics of aerosols at middle Indo-Gangetic Plain: Impacts of regional meteorology and long-range transport. Atmos. Environ. 104, 162-175. DOI: 10.1016/j.atmosenv.2015.01.014 Kumar M., Singh R.K., Murari V., Singh A.K., Singh R.S. and Banerjee T., 2016a. Fireworks induced particle pollution: A spatio-temporal analysis. Atmos. Res. 180, 78-91. DOI: 10.1016/j.atmosres.2016.05.014

Kumar M., Mhawish A., Raju M.P., Singh R.S. and Banerjee, T., 2016b. Characteristics of black carbon aerosols during agro-residue burning seasons over middle Indo-Gangetic Plain. In: Proceedings of Indian Aerosol Science and Technology Association Conference 2016, Ahmedabad, India (vol. 22, 625-628). 
Kumar M., Raju M.P., Singh R.S. and Banerjee T., 2017a. Impact of drought and normal monsoon scenarios on aerosol induced radiative forcing and atmospheric heating in Varanasi over middle Indo-Gangetic Plain. J. Aerosol Sci. 113, 95-107.

DOI: 10.1016/j.jaerosci.2017.07.016

Kumar M., Raju M.P., Singh R.K., Singh A.K., Singh R.S. and Banerjee T., 2017b. Wintertime characteristics of aerosols over middle Indo-Gangetic Plain: Vertical profile, transport and radiative forcing. Atmos. Res. 183, 268-282. DOI: 10.1016/j.atmosres.2016.09.012

Kumar M., Parmar K.S., Kumar D.B., Mhawish A., Broday D.M., Mall R.K. and Banerjee T., 2018. Long-term aerosol climatology over Indo-Gangetic Plain: Trend, prediction and potential source fields. Atmos. Environ. 180, 37-50.

DOI: $10.1016 /$ j.atmosenv.2018.02.027

Laborde M., Crippa M., Tritscher T., Jurányi Z., Decarlo P.F., Temime-Roussel B., Marchand N., Eckhardt S., Stohl A., Baltensperger U. and Prévôt A.S.H., 2013. Black carbon physical properties and mixing state in the European megacity Paris. Atmos. Chem. Phys. 13, 5831-5856.

DOI: $10.5194 /$ acp-13-5831-2013

Lau K.M., Ramanathan V., Wu G.X., Li Z., Tsay S.C., Hsu C., Sikka R., Holben B., Lu D., Tartari G. and Chin M., 2008. The joint aerosol-monsoon experiment: A new challenge for monsoon climate research. B. Am. Meteorol. Soc. 89, 369-384.

DOI: $10.1175 /$ BAMS-89-3-369

Liu J., Fan S., Horowitz L.W. and Levy H., 2011. Evaluation of factors controlling long-range transport of black carbon to the Arctic. J. Geophys. Res.-Atmos. 116. DOI: $10.1029 / 2010 J D 015145$

Menon S., Koch D., Beig G., Sahu S., Fasullo, J. and Orlikowski, D. 2010. Black carbon aerosols and the third polar ice cap. Atmos. Chem. Phys. 10, 4559-4571. DOI: $10.5194 /$ acp-10-4559-2010

MHA, 2011. Census of India. The Registrar General and Census Commissioner, Ministry of Home Affairs, Government of India, New Delhi. Available at: http://www. censusindia.gov.in/2011 common/census_2011.html.

Mhawish A., Banerjee T., Broday D.M., Misra A. and Tripathi S.N., 2017. Evaluation of MODIS Collection 6 aerosol retrieval algorithms over Indo-gangetic plain: Implications of aerosols types and mass loading. Remote Sens. Environ. 201, 297-313.

DOI: $10.1016 /$ j.rse.2017.09.016
MOSPI, 2017a. Statistical Year Book India, 2016. Ministry of Statistics and Programme Implementation, Government of India, New Delhi. Available at: www.mospi. gov.in (last accessed on May 31, 2018).

MOSPI, 2017b. Energy Statistics. Ministry of Statistics and Programme Implementation, Government of India. Available at: www.mospi.gov.in (last accessed on May 20, 2018).

MPNG, 2016. IPNG Statistics 2015-2016. Ministry of Petroleum and Natural Gas, Government of India. Available at: www.petroleum.nic.in (last accessed on May 24, 2018).

MUD, 2016. Handbook of urban statistics. Ministry of Urban Development, Government of India, New Delhi. Available at: www.mohua.gov.in (last accessed on May 21, 2018).

Murari V., Kumar M., Barman S.C. and Banerjee T., 2015. Temporal variability of MODIS aerosol optical depth and chemical characterization of airborne particulates in Varanasi, India. Environ. Sci. Poll. Res. 22, 13291343. DOI: $10.1007 / \mathrm{s} 11356-014-3418-2$

Murari V., Kumar M., Singh N., Singh R.S. and Banerjee T., 2016. Particulate morphology and elemental characteristics: Variability at middle Indo-Gangetic Plain. J. Atmos. Chem. 73, 165-179.

DOI: $10.1007 / \mathrm{s} 10874-015-9321-5$

Murari V., Kumar M., Mhawish A., Barman S.C. and Banerjee T., 2017. Airborne particulate in Varanasi over middle Indo-Gangetic Plain: Variation in particulate types and meteorological influences. Environ. Monit. Assess. 189, 157. DOI: 10.1007/s10661-017-5859-9

Pandey A., Sadavarte P., Rao A.B. and Venkataraman C., 2014. Trends in multi-pollutant emissions from a technology-linked inventory for India: II. Residential, agricultural and informal industry sectors. Atmos. Environ. 99, 341-352.

DOI: 10.1016/j.atmosenv.2014.09.080

Pani S.K. and Verma S., 2014. Variability of winter and summertime aerosols over eastern India urban environment. Atmos. Res. 137, 112-124.

DOI: 10.1016/j.atmosres.2013.09.014.

Putero D., Cristofanelli P., Marinoni A., Adhikary B., Duchi R., Shrestha S.D., Verza G.P., Landi T.C., Calzolari F., Busetto M. and Agrillo G., 2015. Seasonal variation of ozone and black carbon observed at Paknajol, an urban site in the Kathmandu Valley, Nepal. Atmos. Chem. Phys. 15, 13957-13971.

DOI: $10.5194 / \mathrm{acp}-15-13957-2015$ 
Rajput P., Sarin M.M., Rengarajan R. and Singh D., 2011. Atmospheric polycyclic aromatic hydrocarbons (PAHs) from post-harvest biomass burning emissions in the Indo-Gangetic Plain: Isomer ratios and temporal trends. Atmos. Environ. 45, 6732-6740.

DOI: 10.1016/j.atmosenv.2011.08.018

Rajput P., Sarin M.M., Sharma D. and Singh D., 2014a. Organic aerosols and inorganic species from post-harvest agricultural-waste burning emissions over northern India: Impact on mass absorption efficiency of elemental carbon. Environ. Sci-Proc. Imp. 16, 2371-2379.

DOI: $10.1039 /$ C4EM00307A

Rajput P., Sarin M., Sharma D. and Singh D., 2014 b. Characteristics and emission budget of carbonaceous species from post-harvest agricultural-waste burning in source region of the Indo-Gangetic Plain. Tellus B $66,21026$.

DOI: $10.3402 /$ tellusb.v66.21026

Ramanathan V. and Carmichael G., 2008. Global and regional climate changes due to black carbon. Nature Geo. 1, 221. DOI: 10.1038/ngeo156

Rehman I.H., Ahmed T., Praveen P.S., Kar A. and Ramanathan V., 2011. Black carbon emissions from biomass and fossil fuels in rural India. Atmos. Chem. Phys. $11,7289-7299$.

DOI:10.5194/acp-11-7289-2011

Riemer N., West M., Zaveri R. and Easter R., 2010. Estimating black carbon aging time-scales with a particle-resolved aerosol model. J. Aerosol Sci. 41, 143-158. DOI. 10.1016/j.jaerosci.2009.08.009

Sadavarte P. and Venkataraman C., 2014. Trends in multi-pollutant emissions from a technology-linked inventory for India. I. Industry and transport sectors. Atmos. Environ. 99, 353-364.

DOI: 10.1016/j.atmosenv.2014.090.81

Samset B.H. and Myhre G., 2015. Climate response to externally mixed black carbon as a function of altitude.

J. Geophys. Res.-Atmos. 120, 2913-2927.

DOI: 10.1002/2014JD022849

Sedlacek A.J., 2016. Aethalometer instrument handbook (No. DOE/SC-ARM-TR-156). Office of Science Atmospheric Radiation Measurement (ARM) Program, Department of Energy, USA, 36 pp.

Sen A., Abdelmaksoud A.S., Ahammed Y.N., Banerjee T., Bhat M.A., Chatterjee A., Choudhuri A.K., Das T., Dhir A., Dhyani P.P. and Gadi R., 2017. Variations in particulate matter over Indo-Gangetic Plains and Indo-Himalayan Range during four field campaigns in winter monsoon and summer monsoon: role of pollution pathways. Atmos. Environ. 154, 200-224. DOI: 10.1016/j.atmosenv.2016.12.054

Seneviratne M.S., Waduge V.A., Hadagiripathira L., Sanjeewani S., Attanayake T., Jayaratne N. and Hopke P.K., 2011. Characterization and source apportionment of particulate pollution in Colombo, Sri Lanka. Atmos. Poll. Res. 2, 207-212.

DOI: 10.5094/APR.2011.026

Singh N., Mhawish A., Deboudt K., Singh R.S. and Banerjee T., 2017a. Organic aerosols over Indo-Gangetic Plain: Sources, distributions and climatic implications. Atmos. Environ. 157, 59-74.

DOI: 10.1016/j.atmosenv.2017.03.008

Singh N., Murari V., Kumar M., Barman S.C. and Banerjee T., 2017b. Fine particulates over South Asia: Review and meta-analysis of $\mathrm{PM}_{2.5}$ source apportionment through receptor model. Environ. Poll. 223, 121-136.

DOI: 10.1016/j.envpol.2016.12.071

Singh N., Banerjee T., Raju M.P., Deboudt K., Sorek-Hamer M., Singh R.S. and Mall R.K., 2018. Aerosol chemistry, transport, and climatic implications during extreme biomass burning emissions over the Indo-Gangetic Plain. Atmos. Chem. Phys. 18.

DOI: $10.5194 / \mathrm{acp}-18-14197-2018$

Stockwell C.E., Jayarathne T., Cochrane M.A., Ryan K.C., Putra E.I., Saharjo B.H., Nurhayati A.D., Albar I., Blake D.R., Simpson I.J. and Stone E.A., 2016. Field measurements of trace gases and aerosols emitted by peat fires in Central Kalimantan, Indonesia, during the 2015 El Niño. Atmos. Chem. Phys. 16, 11711-11732. DOI: $10.5194 / \mathrm{acp}-16-11711-2016$

Tiwari S., Srivastava A.K., Bisht D.S., Safai P.D. and Parmita P., 2013. Assessment of carbonaceous aerosol over Delhi in the Indo-Gangetic Basin: Characterization, sources and temporal variability. Nat. Haz. 65, 17451764. DOI: $10.1007 / \mathrm{s} 11069-012-0449-1$

Udayasoorian C., Jayabalakrishnan R.M., Suguna A.R., Gogoi M.M. and Babu S.S., 2014. Aerosol black carbon characteristics over a high-altitude Western Ghats location in Southern India. Ann. Geophys. 32, 1361. DOI: 10.5194/angeo-32-1361-2014

Venkataraman C., Habib G., Eiguren-Fernandez A., Miguel A.H. and Friedlander S.K., 2005. Residential biofuels in South Asia: Carbonaceous aerosol emissions and climate impacts. Science. 307, 1454-1456. DOI: $10.1126 /$ science. 1105675 
Virkkula A., Mäkelä T., Hillamo R., Yli-Tuomi T., Hirsikko A., Hämeri K. and Koponen I.K., 2007. A simple procedure for correcting loading effects of aethalometer data. J. Air Waste Manage. Ass. 57, 1214-1222. DOI: $10.3155 / 1047-3289.57 .10 .1214$

Wang M., Xu B., Cao J., Tie X., Wang H., Zhang R., Qian Y., Rasch P.J., Zhao S., Wu G. and Zhao H., 2015. Carbonaceous aerosols recorded in a southeastern Tibetan glacier: Analysis of temporal variations and model estimates of sources and radiative forcing. Atmos. Chem. Phys. 15, 1191-1204.

DOI: 10.5194/acp-15-1191-2015

Wang Q., Jacob D.J., Spackman J.R., Perring A.E., Schwarz J.P., Moteki N., Marais E.A., Ge C., Wang J. and Barrett S.R., 2014. Global budget and radiative forcing of black carbon aerosol: Constraints from pole-to-pole (HIPPO) observations across the Pacific. J. Geophys. Res.-Atmos. 119, 195-206.

DOI: $10.1002 / 2013 J D 020824$
Wang Y., Hopke P.K., Rattigan O.V., Chalupa D.C. and Utell M.J., 2012. Multiple-year black carbon measurements and source apportionment using Delta-C in Rochester, New York. J Air Waste Manage. Ass. 62, 880-887. DOI: 10.1080/10962247.2012.671792

Zhang R., Wang H., Qian Y., Rasch P.J., Easter R.C., Ma P.L., Singh B., Huang J. and Fu Q., 2015. Quantifying sources, transport, deposition, and radiative forcing of black carbon over the Himalayas and Tibetan Plateau. Atmos. Chem. Phys. 15, 6205-6223.

DOI: $10.5194 / \mathrm{acp}-15-6205-2015$ 


\section{Appendix}

Table AI. Seasonal averages of important meteorological variables over Varanasi (2009-2013).

\begin{tabular}{|c|c|c|c|c|}
\hline & Pre-monsoon & Monsoon & Post-monsoon & Winter \\
\hline Temperature $\left({ }^{\circ} \mathrm{C}\right)$ & $30.2 \pm 4.1$ & $30.9 \pm 2.7$ & $24.4 \pm 3.4$ & $17.0 \pm 3.5$ \\
\hline Relative humidity (\%) & $41.5 \pm 12.0$ & $73.1 \pm 16.7$ & $70.2 \pm 9.5$ & $71.2 \pm 12.0$ \\
\hline Sea level pressure $(\mathrm{hPa})$ & $1005.6+4.4$ & $1000.3 \pm 3.3$ & $1011.4 \pm 3.2$ & $1014.8 \pm 2.8$ \\
\hline Visibility $(\mathrm{Km})$ & $4.4 \pm 0.6$ & $4.4 \pm 0.6$ & $3.3 \pm 0.8$ & $2.4 \pm 1.2$ \\
\hline Wind speed $\left(\mathrm{m} \mathrm{s}^{-1}\right)$ & $2.1 \pm 1.1$ & $2.1 \pm 1.3$ & $1.1 \pm 0.9$ & $1.3 \pm 0.8$ \\
\hline
\end{tabular}

Table AII. Pattern of consumption of BC emission sources.

\begin{tabular}{|c|c|c|c|c|c|c|}
\hline & $\begin{array}{l}\text { Coal } \\
(\mathrm{MT})^{\mathrm{a}}\end{array}$ & $\begin{array}{l}\text { Lignite } \\
(\mathrm{MT})^{\mathrm{a}}\end{array}$ & $\begin{array}{l}\text { Crude oil } \\
(\mathrm{MMT})^{\mathrm{a}}\end{array}$ & $\begin{array}{c}\text { Natural gas } \\
\text { (billions of cubic } \\
\text { meters) }\end{array}$ & $\begin{array}{l}\text { Registered } \\
\text { Vehicles }^{\mathrm{c}}\end{array}$ & $\begin{array}{c}\text { Per Capita Petroleum } \\
\text { consumption in UP } \\
(\mathrm{Kg})^{\mathrm{b}}\end{array}$ \\
\hline 2009 & 585 & 34.4 & 186 & 48.3 & 1049619 & 58.7 \\
\hline 2010 & 589 & 37.7 & 196 & 52 & 1442045 & 58.8 \\
\hline 2011 & 642 & 41.9 & 204 & 60.7 & 1613315 & 59.7 \\
\hline 2012 & 688 & 46 & 219 & 53.9 & 1727876 & 61.1 \\
\hline 2013 & 724 & 43.9 & 222 & 49 & 1854642 & 62.6 \\
\hline
\end{tabular}

Source: ${ }^{\mathrm{a}}$ Wang et al., 2015; ${ }^{\mathrm{b}}$ Wang et al., 2014; ${ }^{\mathrm{c}}$ Wang et al., 2012. 


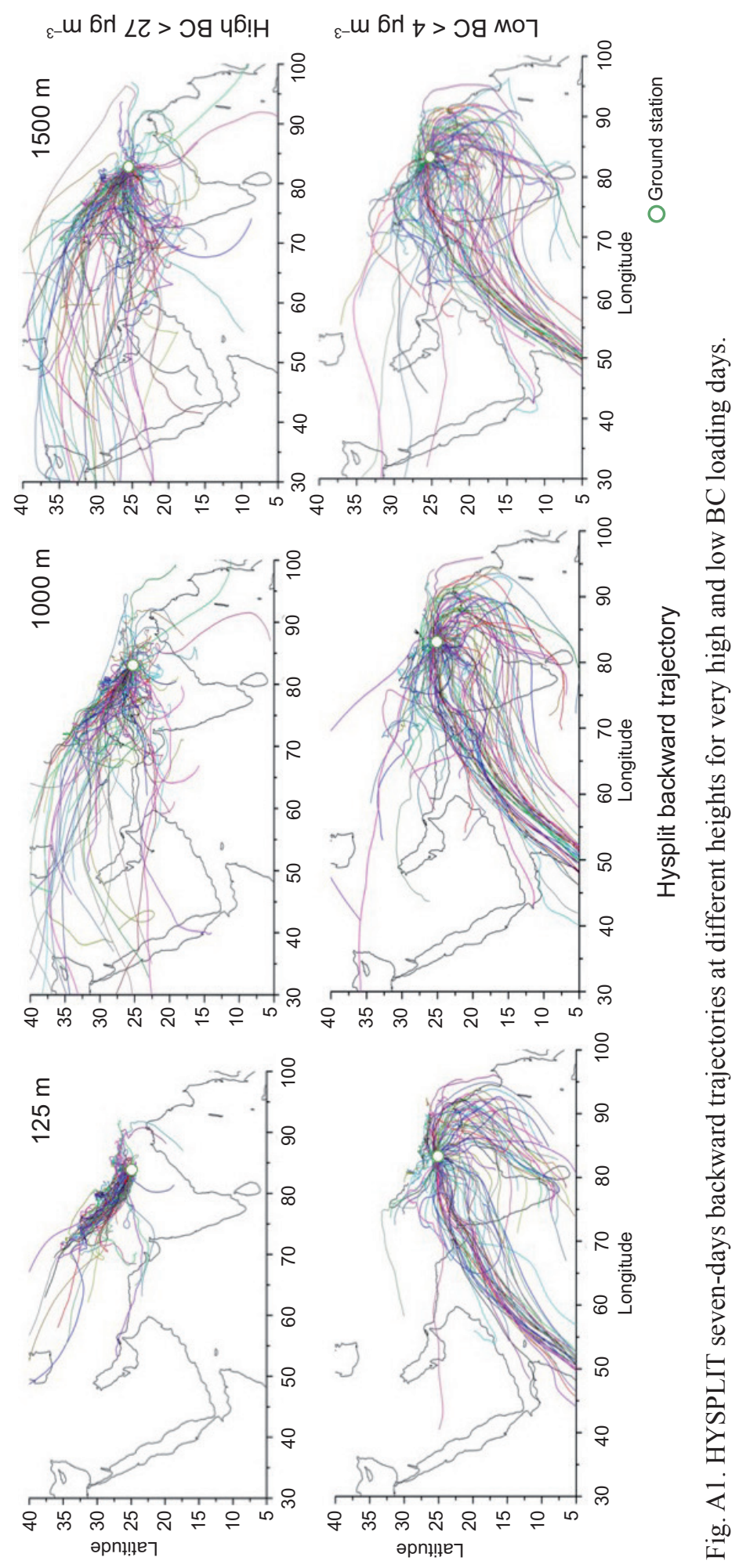




\section{Graphical abstract:}
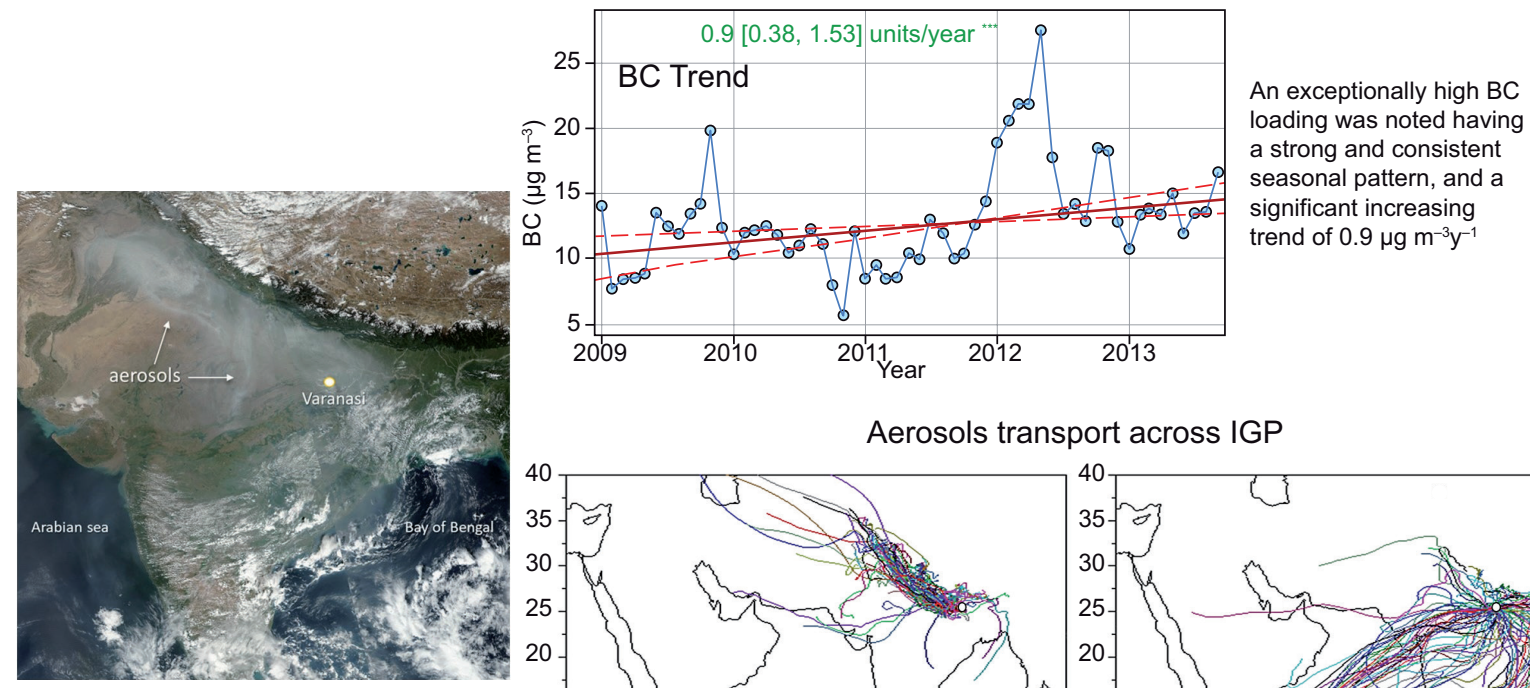

Aerosols transport across IGP

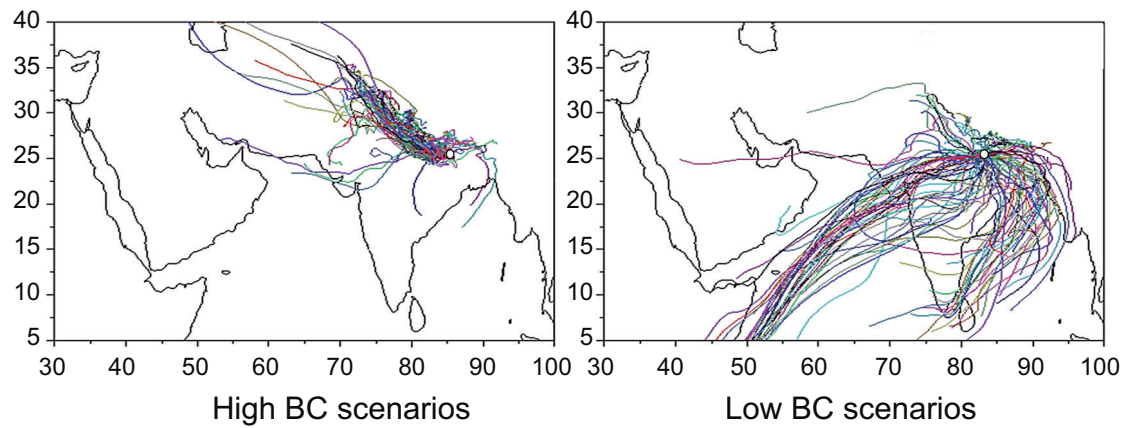

